\title{
Dampak pemutihan karang tahun 2016 terhadap ekosistem terumbu karang: studi kasus di TWP Gili Matra (Gili Air, Gili Meno dan Gili Trawangan) Provinsi NTB
}

\section{Coral bleaching impact in 2016 towards coral reef ecosystem: case studies TWP Gili Matra (Gili Air, Gili Meno and Gili Trawangan) NTB Province}

\author{
Fakhrizal Setiawan $^{1 *}$, Azhar Muttaqin ${ }^{1}$, S.A. Tarigan ${ }^{1}$, Muhidin $^{3}$, Hotmariyah $^{2}$, Abdus Sabil $^{2}$ dan \\ Jessica Pinkan ${ }^{1}$
}

\author{
${ }^{1 *}$ Wildlife Conservation Society - Jl. Tampomas no. 35, Bogor, Jawa Barat. \\ ${ }^{2}$ Balai Kawasan Konservasi Perairan Nasional (BKKPN) Kupang Wilker TWP Gili Matra - Jl. Raya \\ Pemenang-Bangsal, Kec. Pemenang, Kab. Lombok Utara, NTB. \\ ${ }^{3}$ Program Pascasarjana, Institut Pertanian Bogor - Jl. Raya Darmaga Kampus IPB, Dramaga, Bogor, \\ Jawa Barat. \\ *Corresponding author email: fsetiawan@wcs.org
}

Submitted: 13 Mei 2017 / Revised: 22 Desember 2017 / Accepted: 22 Desember 2017

http://dx.doi.org/10.21107/jk.v10i2.2878

\begin{abstract}
Increased sea surface temperatures due to global warming that occurred from the early to mid 2016 caused of coral bleaching in several locations in TWP Gili Matra. Observations of coral bleaching obtained from coral colonies compotition affected by bleaching (50\%), white (18\%), death (1\%) and was not affected (31\%). These implications resulting decline in coral cover but not significant $\left(F_{(1,013)}=\right.$ $0.333, p>0.05$ ) from $23,43 \% \pm 2,61$ SE in 2012 to $18,48 \% \pm 4,14$ SE in 2016 and a significant decrease $\left(P{ }_{(58,06)}=3,8 e^{-06}\right)$ recruitment of coral (coral Juvenil) from 6,66 ind. $m^{-1} \pm 1,04$ SE in 2012 to 1,41 ind. $m^{-1} \pm 0,16 S E$ in 2016. the other impact is a significant reduction $\left(P_{(20.84)}=0,00053, p<0,001\right)$ the abundance of reef fish from 28.733,26 ind. $\mathrm{ha}^{-1} \pm 3.757,89$ SE in 2012 to $11.431,18$ ind.ha ${ }^{-1} \pm 702,53$ $S E$ in 2016 and a decline in the biomass of reef fish but not significant $(F(0,58)=0,46, P>0.05)$ from $506,56 \mathrm{~kg} \cdot \mathrm{ha}^{-1} \pm 99,05 \mathrm{SE}$ in 2012 to $438,41 \mathrm{~kg} \cdot \mathrm{ha}^{-1} \pm$ 45,69 SE in 2016. The decline of coral recruitment resulted in the recovery of the affected areas bleaching becomes slow because of the juvenile new coral mostly dead. The second impact of bleaching is an abundance of fish decrease, indicating that is available only fish big size (adult) and very less of small fishes, including juvenile.
\end{abstract}

Keywords: global warming, coral bleaching, coral cover, reef fishes

\section{ABSTRAK}

Peningkatan suhu permukaan laut akibat pemanasan global yang terjadi dari awal hingga pertengahan tahun 2016 memberikan dampak pemutihan karang di beberapa lokasi di TWP Gili Matra. Hasil pengamatan pemutihan karang didapatkan komposisi dari koloni karang yang terkena pemutihan (50\%), pucat (18\%), mati (1\%) dan tidak terdampak 31\%. Implikasi ini mengakibatkan turunnya tutupan karang namun tidak signifikan $\left(P_{(1.013)}=0.333, p>0,05\right)$ dari $23,43 \% \pm 2,61$ SE di tahun 2012 menjadi $18,48 \% \pm 4,14$ SE di tahun 2016 serta penurunan signifikan $\left(P_{(58,06)}=3,8 e^{-06}\right)$ rekruitmen karang (Juvenil karang) dari 6,66 ind. $m^{-1} \pm$ 1,04 SE di tahun 2012 menjadi 1,41 ind. $m^{-1} \pm 0,16$ SE di tahun 2016. Dampak lainnya yaitu penurunan signifikan $\left(P_{(20,84)}=0,00053, p<0,001\right)$ kelimpahan ikan karang dari 28.733,26 ind. ha $^{-1} \pm$ 3.757,89 SE di tahun 2012 menjadi 11.431,18 ind.ha . $^{-1} \pm$ 702,53 SE di tahun 2016 serta penurunan biomassa ikan karang namun tidak signifikan $\left(P_{(0,58)}=0,46, P>0,05\right)$ dari 506,56 kg.ha-1 \pm 99,05 SE di tahun 2012 menjadi 438,41 kg.ha-1 \pm 45,69 SE di tahun 2016. Dampak bleaching menyebabkan sedikitnya rekrutmen karang yang mengakibatkan proses recovery area terdampak menjadi lambat dikarenakan juvenil karang baru sebagian besar mati. Dampak kedua dari bleaching ini yaitu kelimpahan ikan yang terun signifikan, hal ini mengindikasikan yang tersedia hanya ikan-ikan ukuran besar (dewasa) dan sedikitnya ikan-ikan kecil termasuk juvenile.

Kata kunci: pemanasan global, pemutihan karang, tutupan karang, ikan karang 


\section{PENDAHULUAN}

Pemutihan karang merupakan respon yang biasa terjadi terhadap karang sclreactinia dan alcyonaria, kima, dan anemone yang menyebabkan populasi symbiodinium (alga zooxanthellae) keluar / terdegradasi meninggalkan jaringan tissue karang yang menyebabkan pucat atau putih (HoeghGuldberg, 1999; Douglas, 2003). Kejadian pemutihan karang masal terjadi melibatkan banyak species karang yang cenderung menggambarkan stress lingkungan yang ekstrim (Glynn, 1996). Pemutihan karang masal bisa dikorelasikan dengan gangguan spesifik seperti temperature air yang ektrem tinggi atau rendah, radiasi matahari, sedimentasi, masukan air tawar, kontaminasi /

Peristiwa pemutihan karang merupakan indicator yang bagus akan adanya tekanan lingkungan seperti peningkatan suhu permukaan laut selama El Nino (Tomascik et al., 1997). Pemutihan karang juga terjadi selama fase dingin ENSO (La Nina) pada area-area yang cenderung mengalami peningkatan suhu (Buddemeier et al., 2004). Contoh dari pemutihan karang masal yang cukup fenomenal terjadi tahun 1998 yang disebabkan oleh peningkatan suhu permukaan laut akibat dari kejadian El Nino (Wilkinson 1998), yang dikombinasikan dengan Indian Ocean dipole mode (Saji et al., 1999). Kejadian El Nino terakhir yaitu tahun 20152016 dimana merupakan kejadian terkuat yang pernah didata (Schiemeier, 2015) yang memicu terjadinya pemutihan karang masal yang ke empat dalam sejarah terumbu karang dunia. Pemutihan karang masal tercatat tahun 1982-1983 (Coffroth et al., 1990) selanjutnya tahun 1998 (Wilkinson, 2000) dan 2010 (Heron et al., 2016). El Nino yang terjadi tahun 2015-2016 menyebabkan kematian dan pemutihan karang yang signifikan di seluruh dunia (Ampou et al., 2016) yang menyebabkan beberapa daerah di perairan Indonesia mengalami perubahan suhu permukaan laut seperti di Aceh, Karimunjawa, Lombok, Sulawesi, dan daerah lainnya (Pardede et al., 2016) termasuk TWP Gili Matra di dalamnya.

Taman Wisata Perairan Gili Matra (Gili Meno, Gili Ayer, dan Gili Trawangan) merupakan salah satu kawasan konservasi perairan yang terletak di sebelah utara Pulau Lombok. Luas toksik dan penyakit (Smith and Buddemeier, 1992; Hoegh-Guldberg 1999; Glynn, 1996; Brown, 1997). Faktor peningkatan suhu air laut seringkali diasosiasikan dengan pemanasan global dimana karang termasuk fauna dengan toleransi suhu yang rendah dikarenakan peningkatan suhu sebesar $1^{0}$ $1,5^{\circ} \mathrm{C}$ diatas rata-rata diketahui sudah dapat memicu terjadinya pemutihan karang (Baker et al., 2008; Douglas 2003; Lesser, 2004; Saptarini \& Muzaki 2010). Meskipun batas toleransi karang terhadap suhu bervariasi antar species atau antar daerah pada species yang sama, tetapi hewan karang dan organisme terumbu karang hidup dengan suhu yang dekat batas atas toleransinya (Johannes, 1975).

kawasan konservasi tersebut sebesar 2.954 Ha dengan perincian $665 \mathrm{Ha}$ daratan, 227,65 Ha terumbu karang, 116,82 Ha padang lamun dan 8,24 Ha hutan mangrove (LIPI, 2014). Kawasan konservasi perairan tersebut merupakan salah satu kawasan konservasi yang dikelola oleh Balai Kawasan Konservasi Perairan Nasional (BKKPN) yang berkedudukan di Kupang, Nusa Tenggara Timur dan melalui Satuan Kerja sebagai perwakilan operasional pengelola yang berkedudukan di Kecamatan Pemenang. Secara administratif Taman Wisata Perairan Gili Meno, Gili Ayer, dan Gili Trawangan termasuk dalam lingkup Desa Gili Indah yang terdapat di Kecamatan Pemenang, Kabupaten Lombok Utara (Kartawijaya et al., 2012).

Pada tahun 2012 telah dilakukan kajian ekologi oleh Wildlife Conservation Society (WCS) dan BKKPN satker TWP Gili Matra dengan tujuan mengetahui kondisi ekologi terumbu karang di TWP Gili Matra. Hasil kajian tersebut kemudian digunakan sebagai dasar lokasi yang belum terkena bleaching. Ancaman penurunan kualitas ekosistem terumbu di TWP Gili Matra saat ini berasal dari perubahan iklim global yang mengakibatkan pemutihan karang masal. Kondisi dari fenomena pemutihan karang ini berimbas pada kesehatan ekosistem terumbu karang di TWP Gili Matra. Adapun tujuan studi ini yaitu melihat pengaruh pemutihan terumbu karang terhadap ekosistem terumbu karang di TWP Gili Matra yang terjadi pada periode (sebelum bleaching (2012) dan saat terjadi bleaching (2016). 


\section{MATERI DAN METODE}

\section{Waktu dan Lokasi Pengamatan}

Survei ekologi dilakukan di Taman Wisata Perairan Gili Matra $\left(8^{0} 20^{\prime}-8^{0} 23^{\prime}\right.$ LS ; $116^{0}$ $00^{\prime}-116^{\circ} 08^{\prime}$ BT), Kab. Lombok Utara. Studi kali ini dilakukan Juli 2012 (sebelum terjadinya bleaching) dan Agustus 2016 (saat terjadi bleaching) pada 14 lokasi pengamatan (10 titik di TWP Gili Matra dan 4 titik di mainland sebagai kontrol). Khusus pengambilan data coral bleaching dilakukan pada bulan Mey 2016 (saat suhu permukaan laut paling tinggi) sebanyak 6 titik pengamatan yang mewakili kesemua lokasi baik itu di Gili air, Meno, Trawangan maupun mainland.

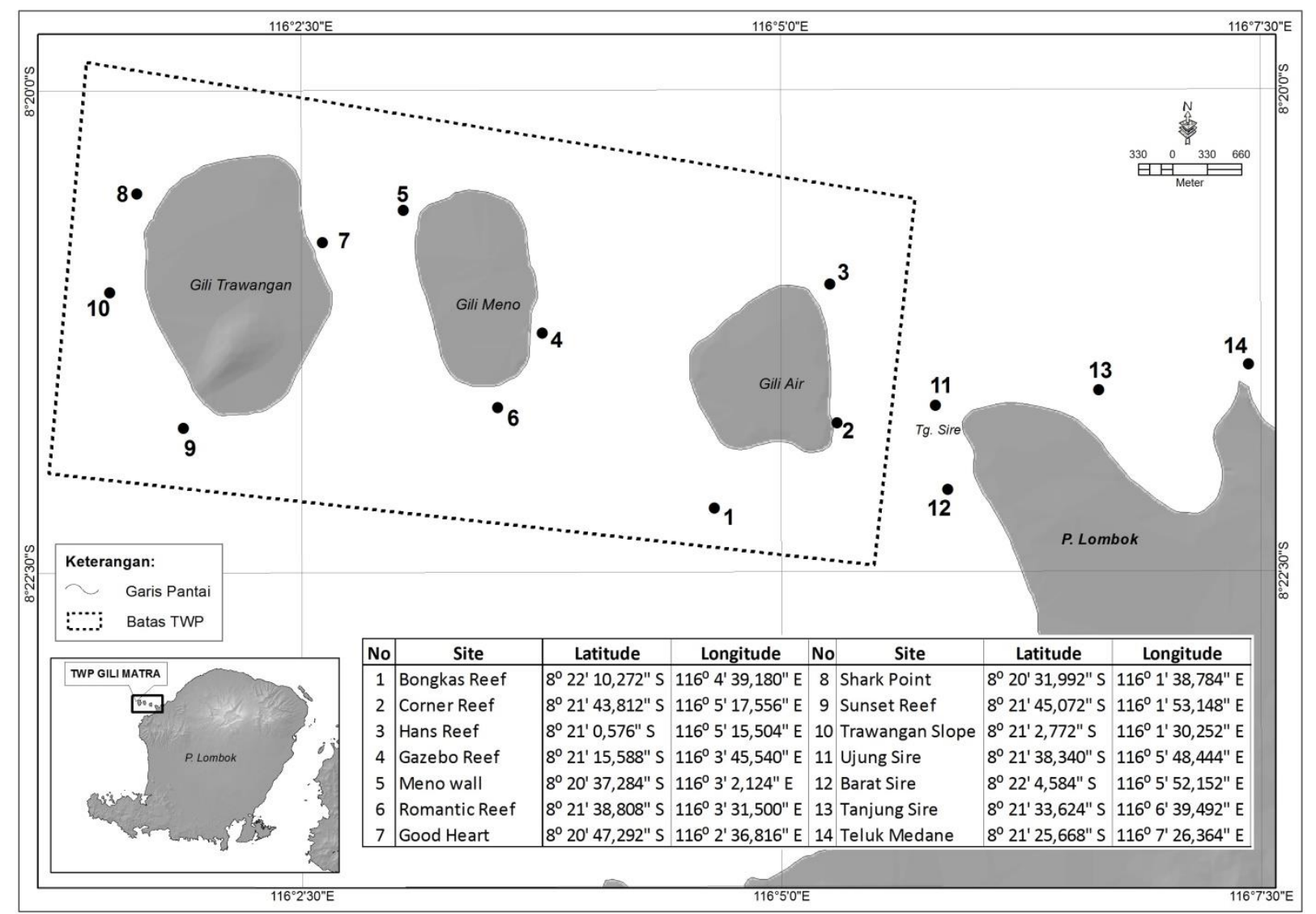

Gambar 1. Peta Lokasi Penelitian di Taman Wisata Perairan Gili Matra.

\section{Terumbu karang}

Metode pengumpulan data tutupan substrat menggunakan Point Intercept Transect (PIT) sepanjang 50 meter dengan mencatat 100 titik substrat mengikuti metode yang dilakukan pada penggamatan tahun 2012 (Hill and Wilkinson, 2004). Pencatatan jenis substrat dimasukan berdasarkan kategori : karang keras (tingkat genera), karang lunak (soft coral), alga (algae), spons (sponge), pasir (sand), patahan karang (rubble), dan lainnya (others). Pengumpulan data dilakukan pada kedalam dangkal (3 - 4 meter) dan dalam (7 10 meter) dengan replikasi sebanyak 3 kali.

Pengumpulan data rekruitmen karang keras menggunakan metode Quadrat Transect (QT) atau transek kuadrat dengan ukuran $50 \times 50$ $\mathrm{cm}$ (Hill and Wilkinson, 2004; Yulianto et al., 2012) yang diletakan berhimpitan dengan PIT disetiap interval 10 meter. Replika QT berjumlah antara 12 hingga 18 replikasi. Pengumpulan data rekruitmen hanya mencatat jumlah koloni dan genera karang yang ukurannya kurang dari $4 \mathrm{~cm}$ disetiap transek kuadrat.

\section{Pemutihan Karang}

Pengamatan dampak pemutihan karang dilakukan menggunakan metode survey cepat (rapid assessment; McClanahan et al., 2001) pada 6 lokasi pengamatan. Pencatatan dilakukan dengan mengestimasi kategori pemutihan pada koloni karang keras secara acak dalam radius $2 \times 2 \mathrm{~m}$ dengan pengulangan 30 kali. Koloni karang dicatat dengan infomasi genera dan diklasifikasikan ke dalam 7 kategori pemutihan, normal, pucat, putih $0-20 \%$, putih $20-50 \%$, putih $50-80 \%$, putih $80-100 \%$ dan mati (Tabel 1) yang mengacu pada Muttaqin et al., (2011). 
Tabel 1. Kategori pemutihan karang (sumber Muttaqin et al., 2011)

\begin{tabular}{ll}
\hline Kondisi & Keterangan \\
\hline Normal & $100 \%$ karang dalam kondisi normal \\
& $>50 \%$ koloni karang normal sisanya pucat dan atau mati \\
\hline Pucat & $100 \%$ koloni karang pucat \\
& $>50 \%$ koloni karang pucat dan sisanya pucat dan atau mati \\
& B1 ( $0-20 \%$ koloni karang putih) \\
& B2 (20-50\% koloni karang putih) \\
Putih & B3 (50-80\% koloni karang putih) \\
& B4 (80-100\% koloni karang putih) \\
\hline Mati & $>50 \%$ koloni karang mati akibat pemutihan karang \\
\hline
\end{tabular}

\section{Ikan Karang}

Parameter ekologis ikan karang yang diamati adalah keragaman jenis (jumlah jenis ikan dalam suatu lokasi), kelimpahan (dalam satuan jumlah per hektare) dan biomasa (dalam satuan kilogram per hektare) dengan visual sensus mengacu pada Yulianto et al., 2012. Analisis perhitungan kelimpahan ikan karang dihitung mengikuti Odum, 1971; Marnane et al., 2004; Hill dan Wilkinson, 2004. Analisis perhitungan biomassa ikan karang mengikuti Bohnsack and Harper, 1988; Kulbicki, 2005.

\section{Analisis statistik}

Analisis statistic dilakukan untuk menguji apakah terdapat perbedaan signifikansi pada setiap sampel penelitian yang di ambil. Untuk menguji perbedaan tersebut dilakukan uji anova dua-arah dan uji-T. Secara umum, maksud dari analisis of variance (ANOVA) adalah untuk menguji signifikansi dari perbedaan antara rataan (Walpole et al., 2012). Uji korelasi Pearson dilakukan juga untuk mengkaji hubungan antara masingmasing parameter ekologi yang ada di TWP Gili Matra. Analisis menggunakan software open source R Studio.

Hasil

Suhu permukaan laut didapatkan dari data satelit NOAA coral watch virtual station, 2016 di periaran Gili Matra. Peningkatan SPL dimulai semenjak desember 2015 dan memuncak hingga terpanas pada bulan Mei 2016 dengan suhu 30,5 $\mathrm{C}$ (Gambar 2). Kenaikan suhu sudah mulai terjadi pada bulan September 2015 sampai pertengahan tahun 2016. Perubahan ini yang mengakibatkan karang tidak dapat mentoleransi kenaikan suhu perairan sehingga menyebabkan terjadinya pemutihan karang di perairan Gili Matra.

Dampak dari perubahan suhu ini menyebabkan adanya pemutihan karang di TWP Gili Matra (Gambar 3). Dari hasil pengamatan pemutihan karang didapatkan komposisi dari koloni karang yang terkena pemutihan sebesar $50 \%$, kondisi pucat $18 \%$, dan dalam kondisi normal 31\%. Kondisi karang yang baru mati akibat pemutihan karang hanya ditemukan sekitar $1 \%$ dari jumlah koloni karang.

Pengamatan pemutihan karang di TWP Gili Matra dilakukan pada 6 lokasi, yaitu Air Wall, Bounty Wreck, Corner Reef, Meno Wall, Sunset Reef, dan Teluk Medane. Pemutihan karang tertinggi dengan persentase rata-rata diatas $60 \%$ ada pada lokasi Sunset Reef, Bounty Wreck, dan Teluk Medane. Pada Teluk Medane juga ditemukan karang mati yang disebabkan karena pemutihan karang sebesar $2 \%$. Sedangkan kondisi karang normal, paling banyak ditemukan pada lokasi Corner Reef sebesar 48\% (Gambar 4). 


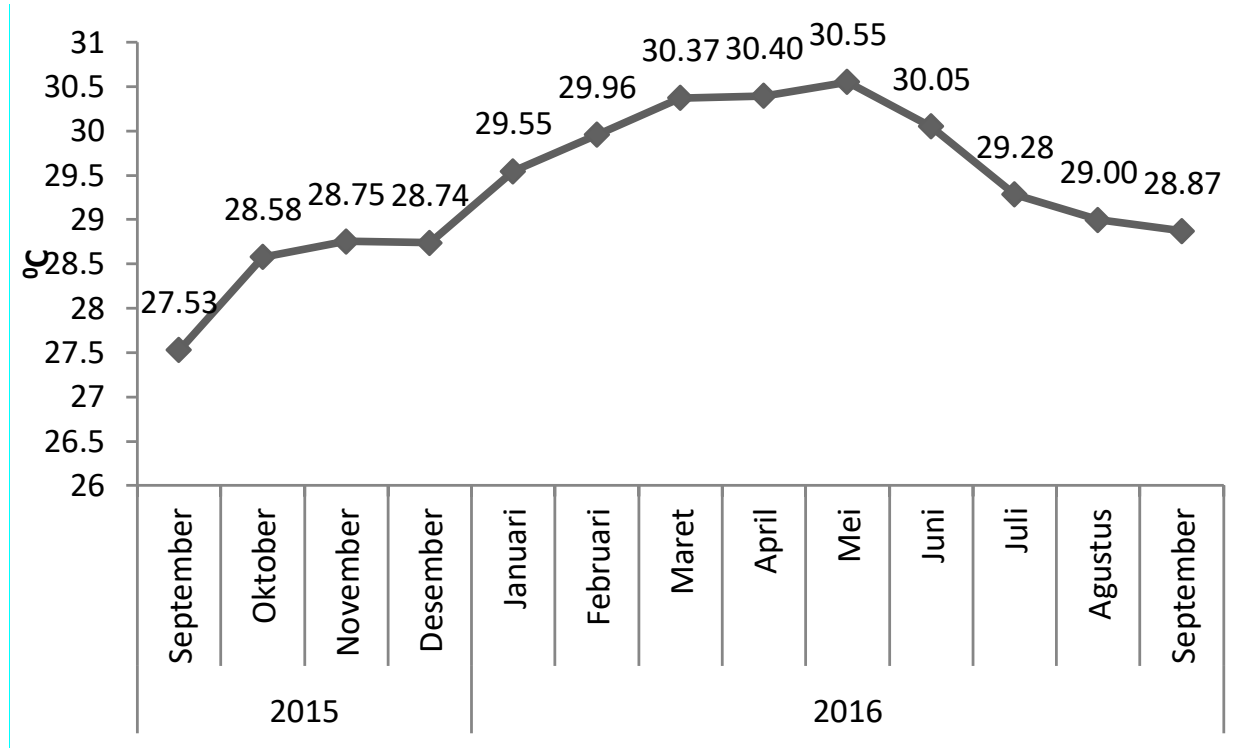

Gambar 2. Suhu permukaan laut di perairan Gili Matra dari September 2015 hingga September 2016 (sumber NOAA, 2016).

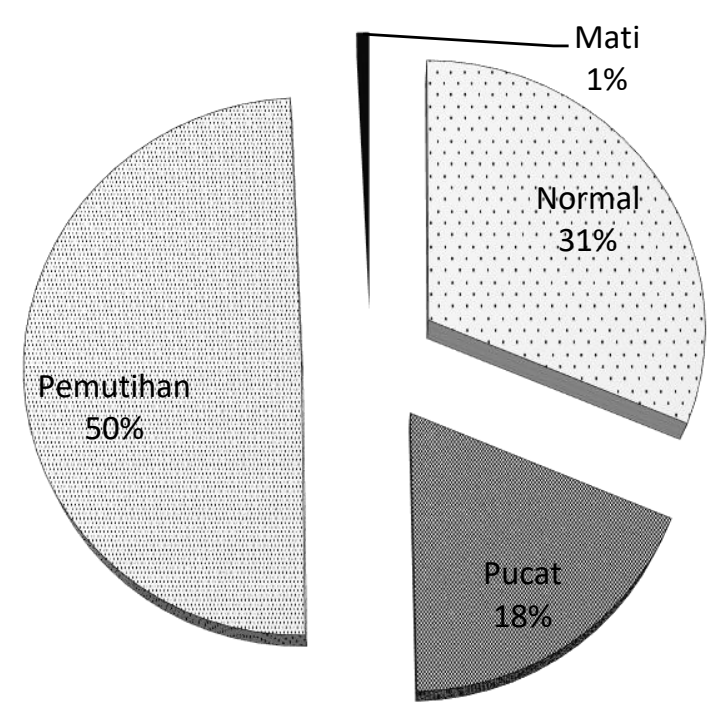

Gambar 3. Komposisi pemutihan karang di TWP Gili Matra.

Berdasarkan genera karang yang ditemukan di TWP Gili Matra, terdapat 31 genera karang keras yang teridentifikasi terkena pemutihan karang dan 1 genera tidak terkena pemutihan karang. Genera Acropora, Porites, Montipora, Seriatopora, dan Favites merupakan genera dengan jumlah koloni tertinggi yang didapatkan dari pengamatan pemutihan karang (Gambar 5). Genera yang banyak ditemukan dalam kondisi memutih di TWP Gili Matra adalah genera Acropora, Heliopora, Stylophora, dan Pocillopora. Genera Acropora, Stylophora, dan Pocillopora merupakan genera yang sangat rentan terhadap pemutihan karang (Prachet et. al., 2013; McClanahan et.al., 2004; Loya et. al., 2001).
Implikasi dari pemutihan karang di TWP Gili Matra menyebabkan tutupan karang mengalami penurunan namun tidak signifikan $\left(P_{(1.013)}=0.333, p>0,05\right)$ dari $23,43 \% \pm 2,61$ SE di tahun 2012 menjadi $18,48 \% \pm 4,14$ SE di tahun 2016. Serta penurunan signifikan $\left(P_{(58,06)}=3,8 \mathrm{e}^{-06}\right)$ rekruitmen karang dari 6,66 ind. $\mathrm{m}^{-1} \pm 1,04$ SE di tahun 2012 menjadi 1,41 ind. $m^{-1} \pm 0,16$ SE di tahun 2016. Hasil uji korelasi pearson untuk melihat hubungan tutupan karang dengan rekrutmen karang memperlihatkan hubungan yang positif $(0,325)$ meski tidak signifikan $(P>0.05)$. 


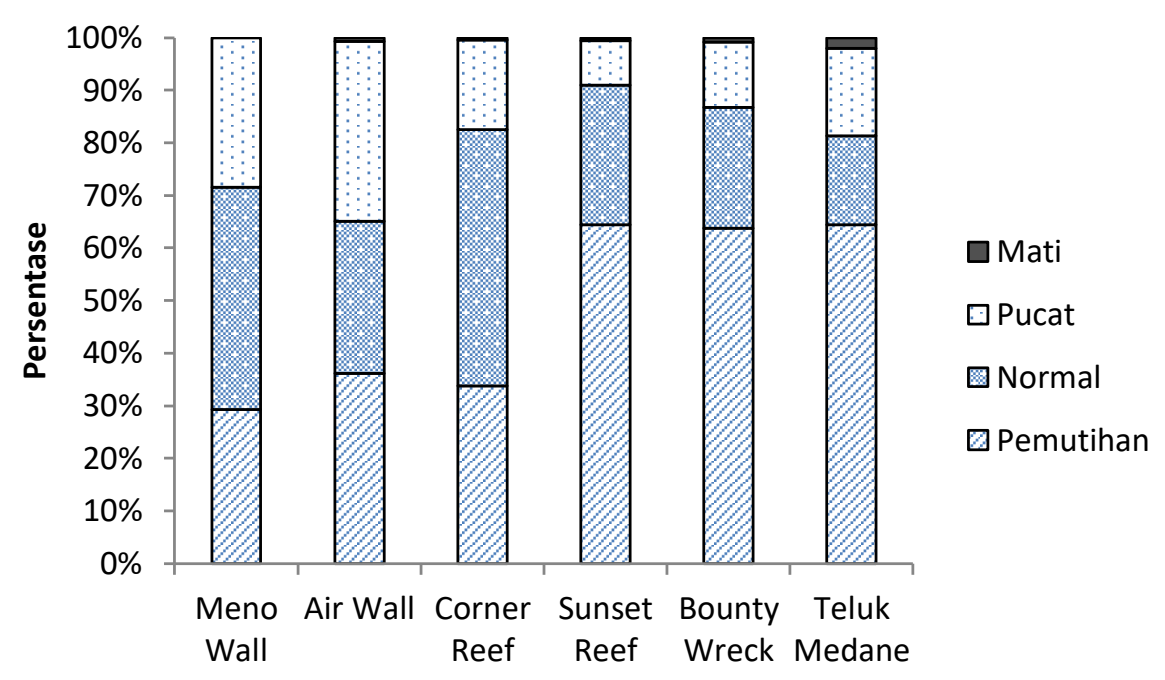

Gambar4. Histogram komposisi pemutihan karang pada setiap lokasi pengamatan.

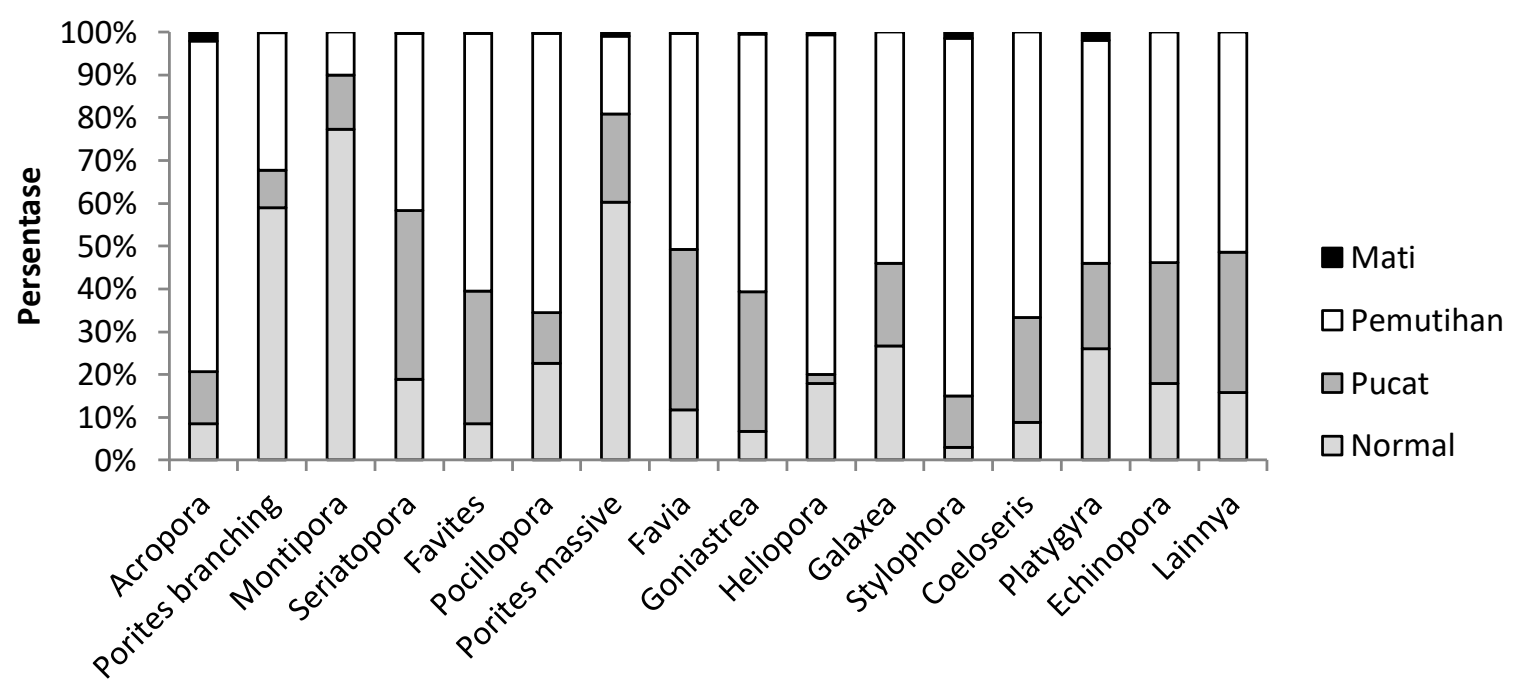

Gambar 5. Histogram komposisi pemutihan karang dari 15 genera karang dengan jumlah koloni tertinggi yang dijumpai di TWP Gili Matra.

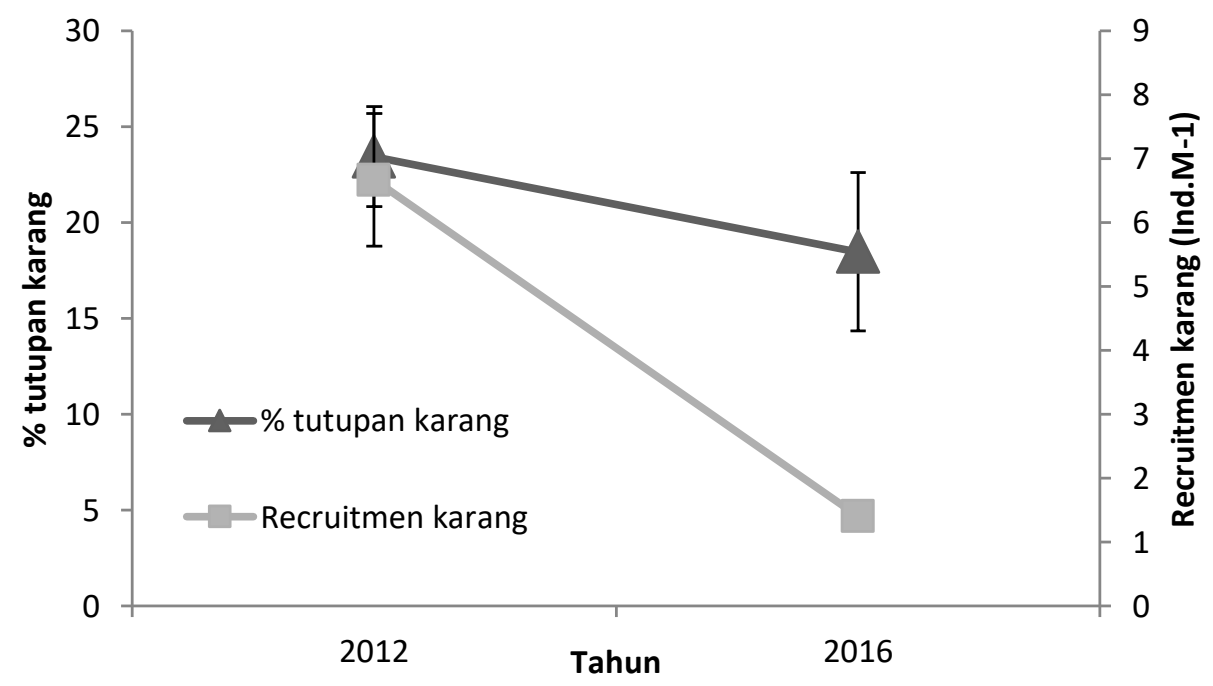

Gambar 6. Rata-rata ( \pm SE) persentase tutupan karang $(\triangle)$ dan recruitmen karang $(\square)$ di TWP Gili Matra. 
Beberapa lokasi mengalami penurunan tutupan karang antara tahun 2012 dengan 2016 yaitu Bongkas Reef $(41,5 \%$ menjadi $8.5 \%)$, Corner Reef $(10,67 \%$ menjadi $3 \%)$, Hans Reef (15\% menjadi 7,83\%), Gazebo reef $(14,83 \%$ menjadi $8 \%)$, Romantic Reef $(42,67 \%$ menjadi 19,17\%), Good Heart (6,67\% menjadi $2,83 \%)$, Sunset reef $(28,5 \%$ menjadi $22 \%)$ dan Trawangan Slope (61,5\% menjadi $31,17 \%)$ namun beberapa lokasi justru mengalami peningkatan seperti Meno Wall (18,67\% menjadi 46\%), Shark Point (20\% menjadi $22,33 \%)$, Bat Sire (9,33\% menjadi 9,83\%),
Tanjung Sire $(23,5 \%$ menjadi $36 \%)$, Teluk Medane (26,67\% menjadi 28,17\%) dan Ujung Sire $(7,67 \%$ menjadi $20 \%)$. Hasil uji Anova menunjukkan tutupan karang tidak ada perbedaan signifikan $(P>0,05)$ antar tahun maupun antar lokasi. Begitu pula perbandingan per pulau dimana Gili Air, Gili Meno dan Gili Trawangan mengalami penuruan tetapi di lokasi Mainland justru mengalami peningkatan. Hasil uji Anova menunjukkan tutupan karang tidak ada perbedaan signifikan $(P>0,05)$ antar tahun maupun antar Pulau (Gambar 7).

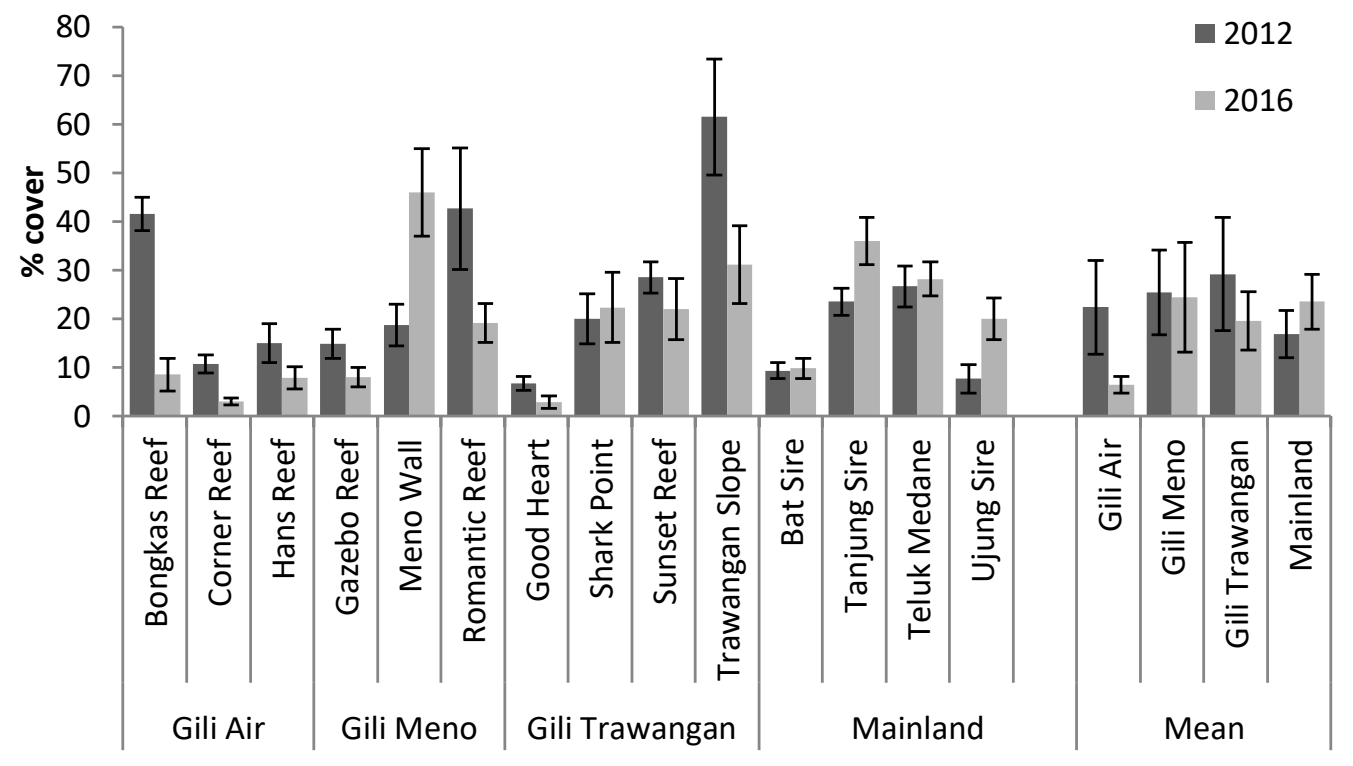

Gambar 7. Histogram rata-rata $( \pm \mathrm{SE})$ persentase tutupan karang keras pada setiap lokasi penelitian tahun 2012 dan 2016.

Dampak pemutihan karang juga berimbas pada rekruitmen karang yang mengalami penurunan di semua lokasi pengamatan antara tahun 2012 dengan 2016 (Gambar 8).
Hasil uji Anova memperlihatkan perbedaan signifikan rekrutmen antar tahun $\left(P_{(58,06)}=3,8^{\mathrm{e}}\right.$ $0,6, P<0,001)$ namun tidak berbeda signifikan $(P>0,05)$ antar lokasi maupun antar pulau.

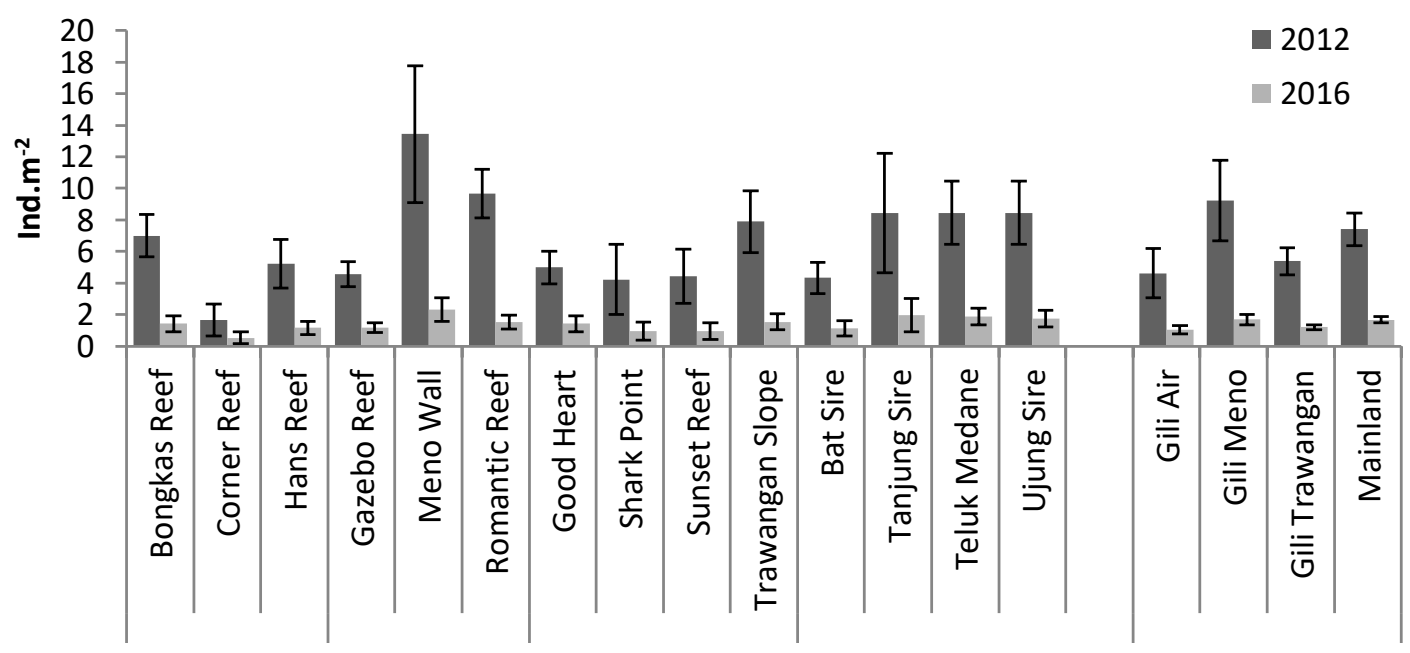

Gambar 8. Histogram nilai rekrutmen karang keras (ind. $\mathrm{m}^{-1} \pm \mathrm{SE}$ ) pada setiap lokasi penelitian tahun 2012 dan 2016. 


\section{Ikan karang}

Dampak pemutihan karang terhadap ikan karang dikaji melalui kelimpahan dan biomassa ikan karangnya. Rata-rata kelimpahan ikan karang mengalami penurunan signifikan $\left(P_{(20,84)}=0,00053, P<0,001\right)$ antar tahun dimana pada tahun 2012 sebesar $28.733,26$ ind.ha ${ }^{-1} \pm$ 3.757,89 SE menjadi $11.431,18$ ind.ha ${ }^{-1} \pm 702,53$ SE di tahun 2016. Rata-rata biomassa ikan karang mengalami penurunan tetapi tidak signifikan $\left(P_{(0,58)}=0,46, P>0,05\right)$ antar tahun dimana tahun 2012 sebesar 506,56 kg.ha-1 \pm 99,05 SE menjadi 438,40 kg.ha-1 \pm 45,69 SE di tahun 2016 (Gambar 9). Hasil uji korealsi pearson memperlihatkan korelasi positif $(0,682)$ antara turunnya kelimpahan dan biomassa tahun 2012 dengan 2016 dengan niai signifikansi $(P<0,001)$.

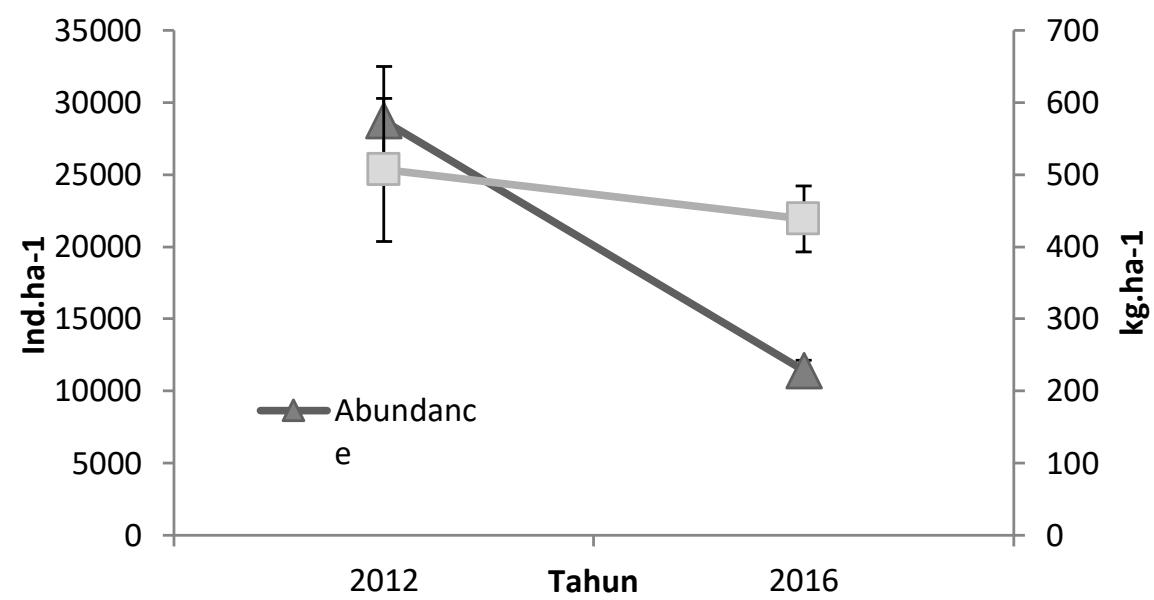

Gambar 9. Rata-rata ( \pm SE) kelimpahan ikan karang $(\square)$ dan recruitmen karang $(\triangle)$ di TWP Gili Matra tahun 2012 dan 2016.

Ikan karang yang tercatat antara tahun 2012 dengan 2016 tidak berbeda jauh dimana tahun 2012 sebanyak 301 species dari 43 famili sedangkan 2016 sebanyak 297 species dari 39 family. Hasil analisis berdasarkan kelimpahan ikan karang memperlihatkan penurunan hampir disemua lokasi kecuali di Ujung sire (Gambar 10). Hasil uji two way anova antara lokasi dan tahun, kelimpahan ikan karang mengalami penurunan signifikan $\left(P_{(20,836)}=0,000531, \quad P<0,001\right) \quad$ dibandingkan tahun 2012, namun tidak ada perbedaan signifikan antar lokasi $(P>0,05)$. Begitu pula rata-rata per pulau dimana mengalami penurunan signifikan $\quad\left(P_{(24,060)}=0,00801\right.$, $\mathrm{P}<0,01)$ antar tahun dan tidak ada perbedaan antar pulau $(P>0,05)$, Gambar 10.

\section{Biomassa ikan karang}

Biomassa ikan karang di beberapa lokasi mengalami penurunan seperti di Bongkas Reef, Hans Reef, Gazebo Reef, Meno Wall, Romantic Reef, Good Heart dan Bat Sire namun lokasi sperti Corner Reef, Shark Point, Sunset Reef, Trawangan Slope, Tanjung Sire, Teluk Medane, Ujung Sire mengalami peningkatan biomassa di tahun 2016 dibandingkan tahun 2012. Hasil uji Anova dua arah menunjukan tidak ada perbedaan signifikan ( $P>0,05)$ biomassa ikan karang antara tahun 2012 dengan 2016 baik antar tahun ,lokasi maupun antar pulau di TWP Gili Matra (Gambar 11).

Perbandingan antar tahun pada kelompok tipe pemakan menunjukan penurunan keseluruhan kelompok trophic. Kelompok Omnivore dan planktivore yang ditemukan cukup dominan juga menggalami penurunan yang signfikan sementara kelompok benthic invertivora, carnivore, coralivora, herbivore dan omnivore ditemukan kelimpahan yang rendah (Gambar 12). Hasil analisis uji t-test antar tahun didapatkan perbedaan signifikan untuk semua kelompok trophic $(P<0,05)$, sedangkan untuk kelompok coralivora karena data yang tidak homogen maka dilakukan pengujian analisis non parametric- mann Whitney. Hasil penggujian tersebut juga didapatkan perbedaan signifikan antar tahun (Asymp sig $<0,05)$. Perbandingan kelompok trophic pada biomassa ikan karang terlihat penurunan seperti di kelompok bentik invertivore, carnivore, coralivore, omnivore dan planktivore namun terdapat juga peningkatan seperti kelompok detritivore dan herbivore (Gambar 12). Hasil uji statistika menggunakan t-test pada kelompok trophic tidak terdapat perbedaan signifikan biomassa ikan antar tahun untuk semua kelompok trophic $(P>$ $0,05)$, kecuali pada kelompok detrivora ditemukan mengalami perbedaan signifikan 
antar tahun $(\mathrm{P}<0,05)$. Pada kelompok herbivora karena data yang tidak homogen maka dilakukan analisis non parametric- Mann
Whitney. Hasil penggujian tersebut didapatkan tidak ada perbedaan signifikan antar tahun (Asymp sig $>0,05$ ).

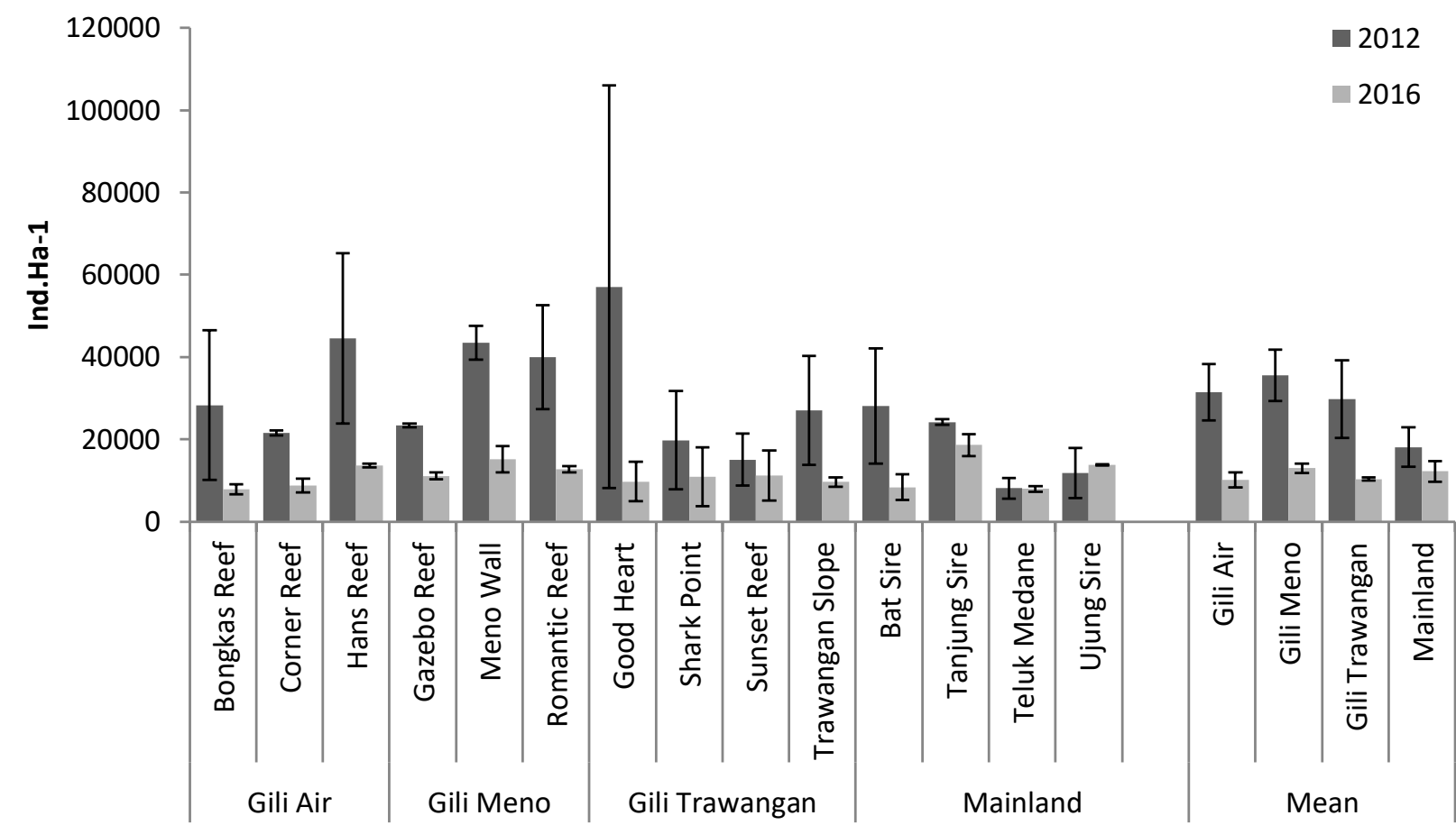

Gambar 10. Perbandingan rata-rata ( \pm SE) kelimpahan ikan karang (Ind.ha-1) tahun 2012 dengan 2016.

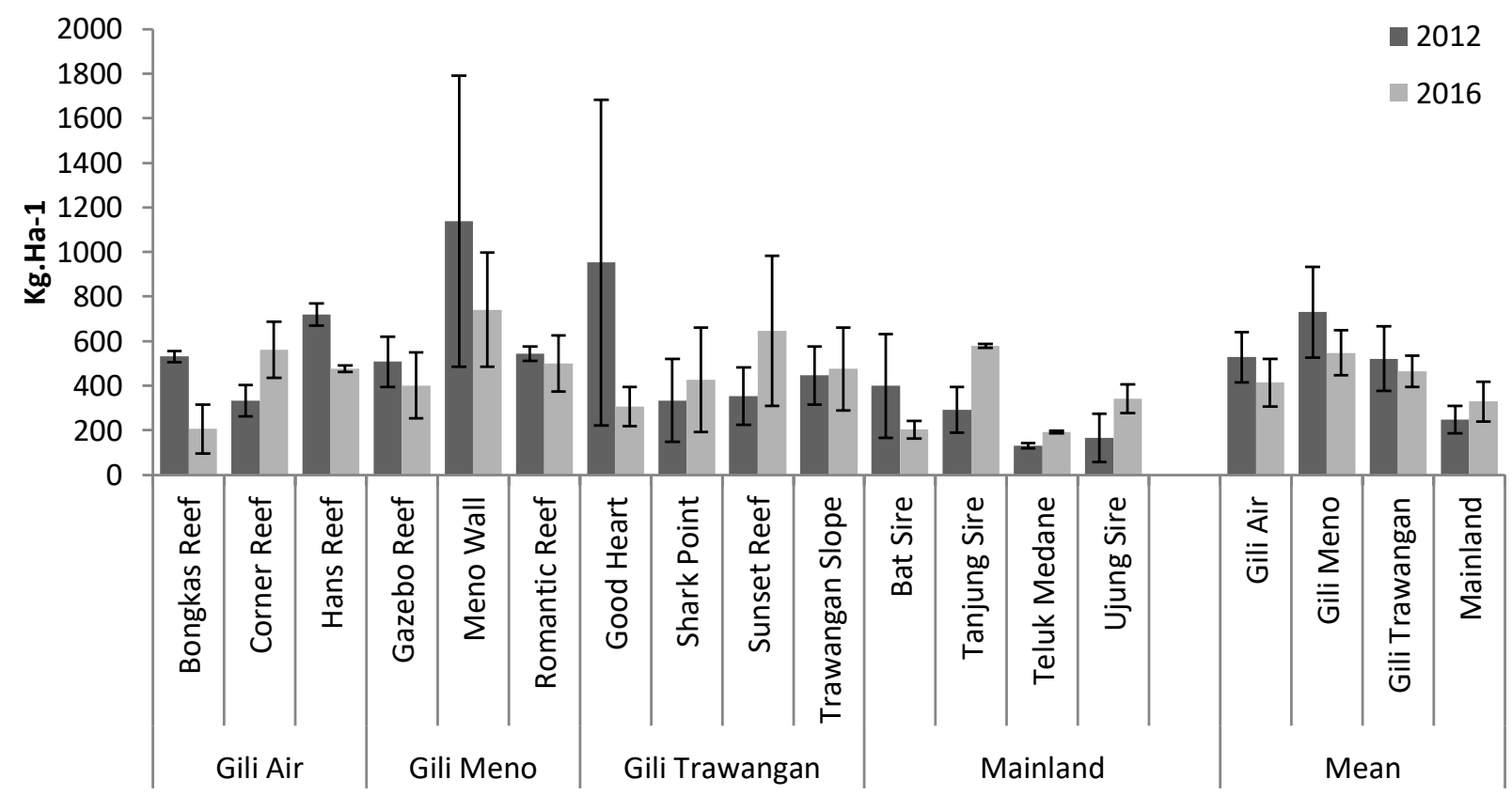

Gambar 11. Perbandingan rata-rata ( \pm SE) biomassa ikan karang $\left(\mathrm{kg} \cdot \mathrm{ha}^{-1}\right)$ antara tahun 2012 dan 2016. 

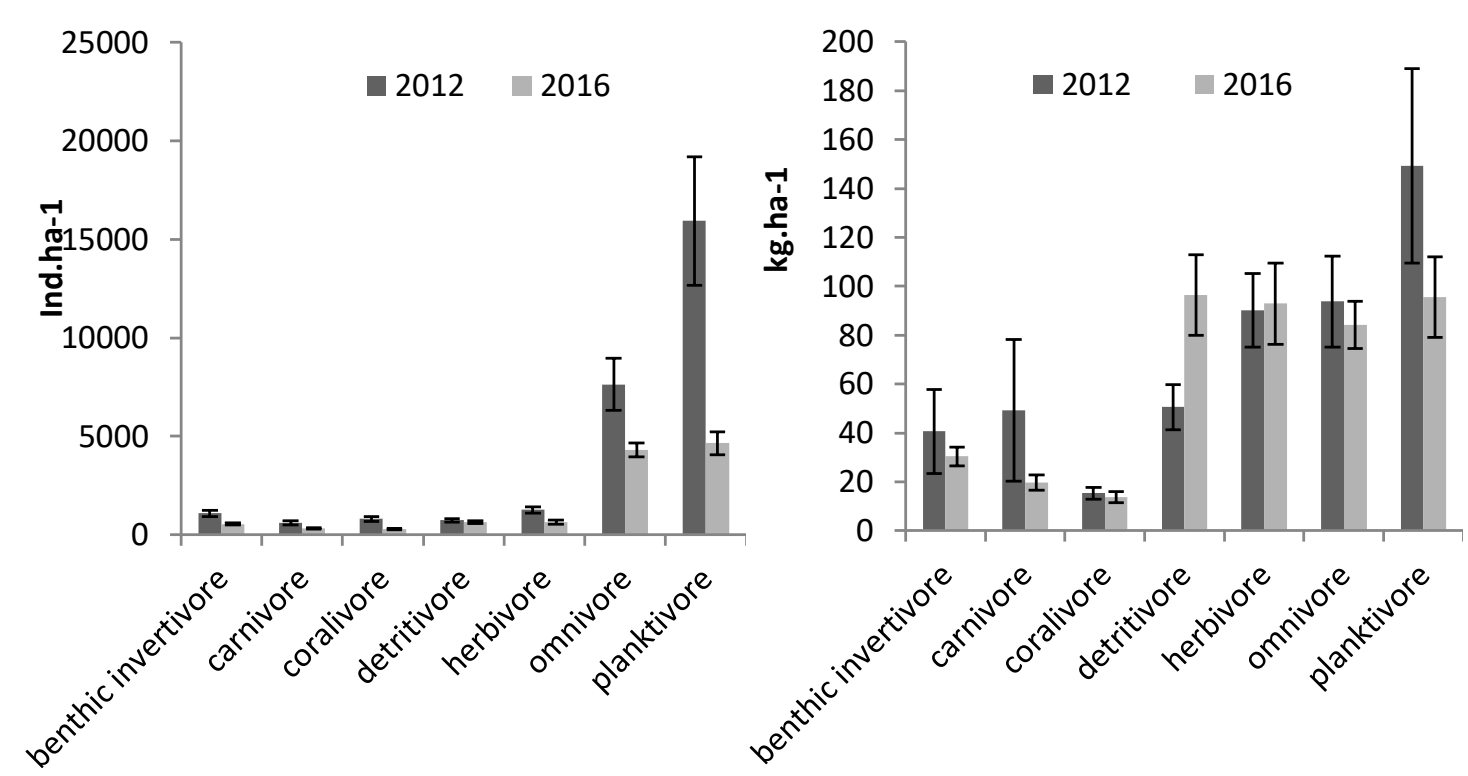

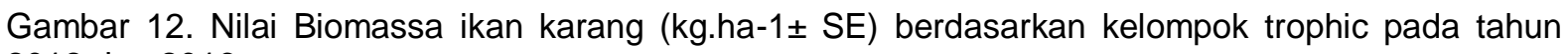
2012 dan 2016.

\section{Diskusi}

Peristiwa pemutihan karang dalam sekala besar dipengaruhi oleh naik-turunnya suhu permukaan laut (Westmacott, 2000; Rudi, 2012). El Nino merupakan penyimpangan iklim yang diindikasikan naiknya suhu permukaan laut (Endlicher, 2001; Hupfer et al., 2001). Saat terjadinya El Nino aliran panas dari perairan Pasifik bagian barat menuju ke daerah perairan Pasifik bagian timur yang lebih dingin yang mengakibatkan peningkatan suhu permukaan laut secara signifikan. Dampak pemutihan karang terhadap ekosistem terumbu karang sangat besar, selain mengakibatkan kematian karang secara luas, pemutihan juga berdampak pada berkurangnya tingkat keanekaragaman sumberdaya alam (Muttaqin et al., 2014). Kejadian pemutihan karang tahun 1998 menyebabkan kehilangan $16 \%$ terumbu karang dunia (Wilkinson, 2000). Sekitar $90 \%$ karang mati akibat pemutihan tahun 1998 di Sumatra Barat dan Gili Matra, Lombok (Salim, 2012).

Kejadian bleaching selanjutnya tahun 2010 mengakibatkan $\quad 35 \% \quad$ karang keras(scleractinians) yang memutih mengalami kematian di bagian utara Aceh (Muttaqin et al., 2014) dan sekitar 60\% karang keras di sekitar Sabang, Pulau Weh mati pasca kejadian bleaching (Rudi et al., 2012). Dampak kejadian pemutihan karang menyebabkan $65 \%$ karang di wakatobi tahun 2010-2011 mengalami bleaching meski yang dilaporkan sebanyak kurang dari $5 \%$ yang mati (Wilson et al., 2012). Dampak bleaching menyebabkan kekayaan species ikan konsumi yang ditangkap di perairan kota sabang, Pulau Weh mengalami penurunan sekitar $50 \%$ pasca coral bleaching tahun 2010 (Rudi et al., 2012). Indikasi yang menunjukkan karangkarang mati terjadi setelah 40 minggu pasca tanda-tanda awal bleaching (Baird and Marshall, 2002).

Terumbu karang di TWP Gili Matra mengalami bleaching semenjak awal tahun 2016 dimana dan genera-genera karang keras yakni Acropora, Pocillopora, Isopora, Montipora, Echinophora dan Stylophora mengalami tingkat kematian paling tinggi disetiap lokasi pemutihan yang tercatat dan termasuk ke dalam genera yang paling rentan terhadap pemutihan karang (Muttaqin et al., 2014; Prachet et al., 2013; Marshal and Schuttenberg, 2006; McClanahan et al., 2004; Loya et al., 2001). Tingkat kerentanan suatu lokasi terhadap pemutihan karang tidak ditentukan hanya oleh indek pemutihan karang, karakter habitat, tutupan karang dan kekayaan genera. Akan tetapi parameter yang paling berpengaruh siginifikan terhadap kerentanan terhadap pemutihan karang adalah kelimpahan dari genera-genara yang rentan seperti Acropora, Isopora, Seriatopora, stylophora dan Pocillopora (Marshall and Baird, 2000; Muttaqin et al., 2014) dan Montipora (Muttaqin et al., 2014) serta paling cepat mati jika terkena bleaching (Baird and Marshall, 2002). Semakin besar tutupan genera-genera karang tersebut semakin rentan suatu lokasi tersebut terhadap 
pemutihan karang. Namun jenis yang bertumbuh lambat dan berbentuk massive seperti Favites, Favia, Goniostrea, Astreopora dan Turbinaria lebih sulit mengalami bleaching (Muttaqin et al., 2014).

Nilai komposisi genera karang yang rentan, sedang dan resisten terhadap bleaching karang di TWP Gili Matra, didapatkan hampir semua lokasi memiliki tingkat kerentanan terhadap bleaching. Beberapa lokasi seperti Shark Point dan Trawangan Slope meski memiliki tutupan genera-genera yang resisten cukup banyak namun genera yang rentan jauh lebih banyak lagi (Gambar 13). Rekrutmen karang-karang muda berperan penting dalam pemulihan dan rekolonisasi pasca coral bleaching. Jenis-jenis karang muda yang mampu bertahan dan pulih dapat memberikan perubahan struktur komunitas karang dari sebelumnya secara substansial (Westmacott et al., 2000).

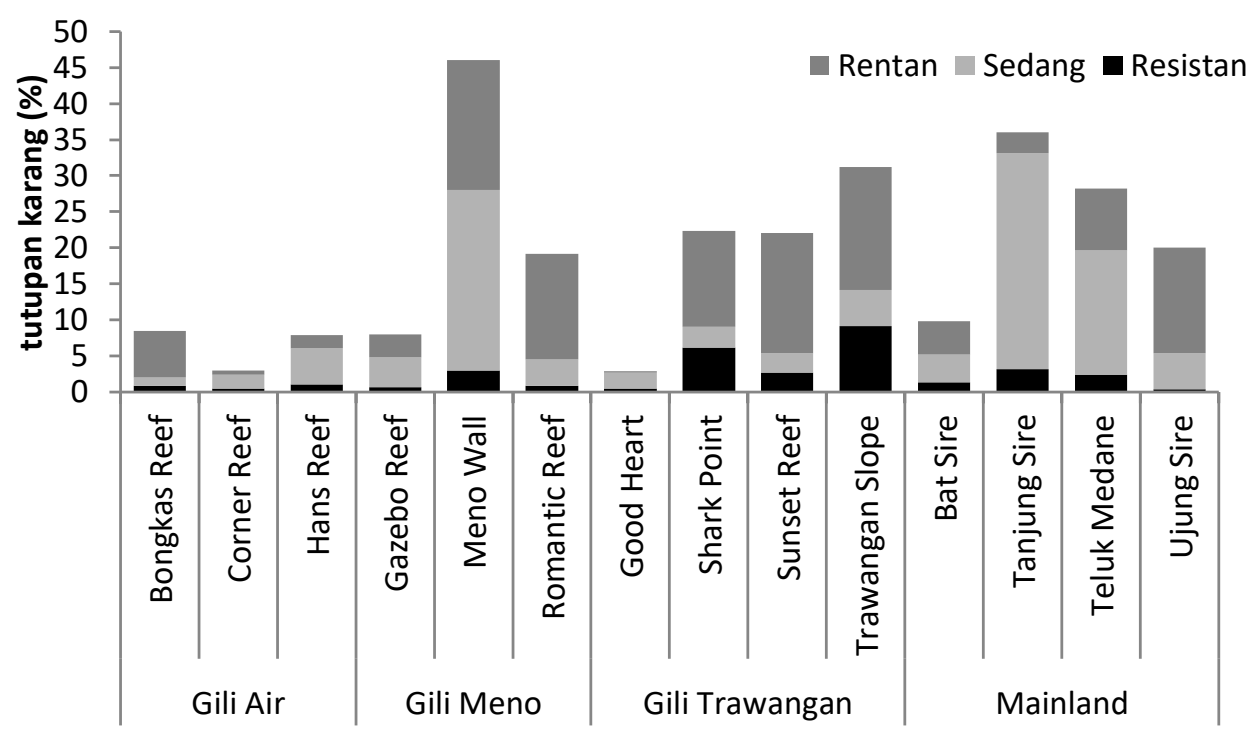

Gambar 13. Histogram komposisi genera karang yang resistan, sedang dan rentan terhadap coral bleaching per lokasi di TWP Gili Matra.

Sejalan dengan turunnya tutupan karang dan rekrutmen karang akibat pemutihan karang, kelimpahan dan biomassa ikan karang juga mengalami penurunan di TWP Gili Matra. Hilangnya terumbu karang paling berdampak terhadap ikan yang tergantung pada terumbu karang untuk hidup/tinggal dan banyak yang menghadapi resiko kepunahan akibat meningkatnya frekuensi bleaching (Pratchett et al., 2008). Turunnya kelimpahan ikan karang secara signifikan diikuti turunnya biomassa namun tidak signifikan dimana ikan dari kelompok planktivora dan omnivore yang paling banyak mengalami penurunan kelimpahannya. Kedua tipe pemakan tersebut mayoritas diisi oleh ikan famili Pomacentridae dan Anthinae-sub famili Serranidae dimana kedua kelompok ikan tersebut berukuran kecil $(<10 \mathrm{~cm})$ berasosiasi kuat dengan karang bercabang. Hilangnya kedua kelompok ikan tersebut dikarenakan banyaknya karang bercabang umumnya dari genus Acropora yang mengalami bleaching. Terumbu karang menyediakan rumah dan perlindungan dari para predator, khususnya bagi ikan berjenis kecil dan ini mempengaruhi pola kelangsungan hidup dan kelimpahannya saat dewasa (Eggleston, 1995). Biomassa ikan karang yang mengalami penurunan namun tidak signifikan mengindikasikan banyaknya ukuran ikan kecil yang kelimpahannya tinggi yang tidak ditemukan lagi di tahun 2016.

Ikan karang dan terumbu karang memiliki hubungan dan keterkaitan yang erat dimana dalam proses koevolusi, ikan karang tumbuh dan berkembang seiring dengan berkembangnya terumbu karang sebagai habitatnya (Muttaqin et al., 2014). Dampak jangka lama dari pemutihan terjadi jika susunan struktur terumbu karang secara fisik hancur akan berakibat pada penurunan keanekaragaman spesies ikan karang (Garpe et al., 2006; Glynn 2006; Graham et al., 2006 in Graham et al., 2007). Proses pemulihan karang pasca bleaching banyak tergantung pada keanekaragaman komunitas (Grimsditch and Salm, 2006) terutama kelimpahan ikan herbivora yang memakan alga (Hughes et al., 2006). Ikan herbivora berperan mengurangi alga sehingga karang muda dan karang dewasa yang sedang dalam pemulihan dapat berkembang lagi. Hasil data survey, kelimpahan ikan herbivora mengalami 
penurunan sedangkan biomassanya mengalami peningkatan namun tidak signifikan sehingga kemungkinan proses recovery dapat berjalan. Pemulihan karang keras pasca gangguan berbanding lurus dengan pemulihan komunitas ikan karangnya (Emslie et al., 2008). Pemulihan karang keras pasca bleaching dapat terjadi jika tidak ada intervensi gangguan saat pemulihan (Pratchett et al., 2006) seperti kasus di Amed, Bali, dimana karang keras membutuhkan waktu 3 tahun (Simarangkir et al., 2015) untuk pulih.

\section{KESIMPULAN DAN SARAN}

Adanya kenaikan suhu di perairan Gili Matra yang puncaknya terjadi pada bulan Mei, menimbulkan dampak yang cukup berpengaruh terhadap kondisi ekosistem terumbu karang pada tahun 2016. Koloni karang yang terkena pemutihan sebesar $50 \%$,sedangkan koloni dengan kondisi pucat sebesar $11 \%$, dan koloni yang ditemukan dalam kondisi normal mencapai 31\%. Karang mati yang disebabkan akibat pemutihan hanya sebasar $1 \%$. Penurunan tutupan karang keras di perairan Gili Matra mengalami penurunan dari tahun $2012(23,43 \% \pm 2,61 \mathrm{SE})$ hingga $2016(18,48 \% \pm 4,14 \mathrm{SE})$ tetapi penurunan yang terjadi tidak signifikan $\left(P_{(1.013)}=0.333, p>\right.$ $0,05)$. Kepadatan rekrutmen karang keras juga terjadi penurunan dari 6,66 ind. $\mathrm{m}^{-1} \pm 1,04 \mathrm{SE}$ di tahun 2012 menjadi 1,41 ind. $\mathrm{m}^{-1} \pm 0,16 \mathrm{SE}$ di tahun 2016, penurunan tersebut terjadi secara signifikan $\left(P_{(58,06)}=3,8 \mathrm{e}^{-06}\right)$. Genera karang memiliki tingkat ketahan terhadap pemutihan karang masing-masing yang dibagi menjadi tiga kategori yaitu rentan, sedang, dan resistan. Air Core, Tanjung Sire, Corner Reef, Good Heart, dan Hans Reef merupakan lokasi dengan tingkat resistan yang tinggi dibandingkan lokasi lainnya, sehingga lokasi tersebut memiliki kemampuan untuk pulih lebih tinggi.

Penurunan kelimpahan dan biomassa ikan yang terjadi di perairan Gili Matra juga dimungkinan dari dampak terjadinya pemutihan karang. Kelimpahan ikan karang mengalami penurunan signifikan $\left(P_{(20,84)}=0,00053, P<0,001\right)$ antar tahun dimana pada tahun 2012 sebesar $28.733,26$ ind.ha $^{-1} \pm$ $3.757,89$ SE menjadi $11.431,18$ ind.ha ${ }^{-1} \pm$ 702,53 SE di tahun 2016. Sama halnya dengan biomassa yang mengalami penurunan dari tahun 2012 ke tahun 2016 tetapi tidak secara signifikan $\quad\left(P_{(0,58)}=0,46, P>0,05\right)$. Penurunan kelimpahan dan biomassa ikan karang yang terjadi juga melingkupi kelimpahan dan biomassa dari ikan herbivora, yang berfungsi sebagai pengontrol keberadaan alga dalam proses pemulihan ekosistem terumbu karang. Walaupun terjadi penurunan tersebut, proses pemulihan dimungkinkan akan tetap berlangsung karena penurunan biomassa ikan herbivora tidak terlihat signifikan.

\section{UCAPAN TERIMA KASIH}

Penulis mengucapkan terimkasih kepada Wildlife Conservation Society - Indonesia Program yang telah menyelenggarakan peneltian ini, BKKPN Kupang satker Gili Matra sebagai mitra dalam proses penelitian yang dilakukan di Gili Matra, Salim Cottage Gili Air sebagai penyedia jasa akomodasi selama penelitian berlangsung, dan semua pihak yang telah membantu demi terlaksananya penelitian di TWP Gili Matra tahun 2016.

\section{DAFTAR PUSTAKA}

Eghbert, E. A., Johan, O., Menkes, C. E., Niño, F., Birol, F., Ouillon, S., \& Andréfouët, S. (2017). Coral mortality induced by the 2015-2016 El-Niño in Indonesia: the effect of rapid sea level fall. Biogeosciences, 14(4), 817.

Baird, A. H., \& Marshall, P. A. (2002). Mortality, growth and reproduction in scleractinian corals following bleaching on the Great Barrier Reef. Marine Ecology Progress Series, 237, 133-141.

Baker, A. C., Glynn, P. W., \& Riegl, B. (2008). Climate change and coral reef bleaching: An ecological assessment of long-term impacts, recovery trends and future outlook. Estuarine, coastal and shelf science, 80(4), 435-471.

Bohnsack, J. A., Harper, D. E., \& Center, S. F. (1988). Length-weight relationships of selected marine reef fishes from the southeastern United States and the Caribbean. National Oceanic and Atmospheric Administration (NOAA). National Marine Fisheries Service, Southeast Fisheries Center, $31 \mathrm{p}$.

Brown, B. E. (1997). Coral bleaching: causes and consequences. Coral reefs, 16(1), S129-S138.

Buddemeier, R. W., Kleypas, J. A., \& Aronson, R. B. (2004). Potential contributions of climate change to stresses on coral reef ecosystems. Coral reefs and global climate change. Pew Center on Global Climate Change, Virginia, USA. 
Coffroth, M. A., Lasker, H. R., \& Oliver, J. K. (1990). Coral mortality outside of the eastern Pacific during 1982-1983: relationship to El Nino. In Elsevier oceanography series (Vol. 52, pp. 141-182). Elsevier.

Douglas, A. E. (2003). Coral bleaching-how and why? Marine pollution bulletin, 46(4), 385-392.

Eggleston, D. B. (1995). Recruitment in Nassau grouper Epinephelus striatus: post-settlement abundance, microhabitat features, and ontogenetic habitat shifts. Marine Ecology Progress Series, 124(1-3): 9-22.

Emslie, M. J., Cheal, A. J., Sweatman, H., \& Delean, S. (2008). Recovery from disturbance of coral and reef fish communities on the Great Barrier Reef, Australia. Marine Ecology Progress Series, 371, 177-190.

Endlicher, W. (2001). Terrestial Impact of the Southern Oscillation and Related El Niño and La Niña events. Pp.52-54 in Climate of the $21^{\text {st }}$ Century: Changes and Risk: Scientific Facts (JL Lozán, H GraßI, and P Hupfer, eds.). Wissenschaftliche Auswertungen, Hamburg.

Garpe, K. C., Yahya, S. A., Lindahl, U., \& Öhman, M. C. (2006). Long-term effects of the 1998 coral bleaching event on reef fish assemblages. Marine Ecology Progress Series, 315, 237-247.

Glynn, P. W. (1996). Coral reef bleaching: facts, hypotheses and implications. Global change biology, 2(6), 495-509.

Glynn, P. W. (2006, June). Fish utilization of simulated coral reef frameworks versus eroded rubble substrates off Panama, eastern Pacific. In Proceedings of the 10th International Coral Reef Symposium (Vol. 1, pp. 250-256).

Graham, N. A., Wilson, S. K., Jennings, S., Polunin, N. V., Robinson, J. A. N., Bijoux, J. P., \& Daw, T. M. (2007). Lag effects in the impacts of mass coral bleaching on coral reef fish, fisheries, and ecosystems. Conservation biology, 21(5), 1291-1300.

Grimsditch, G. D., \& Salm, R. V. (2006). Coral reef resilience and resistance to bleaching. IUCN, The World Conservation Union.

Heron, S.F, Eakin C.M., van Hooidonk R., Maynard J.A. (2016). Coral Reefs. In Laffoley $\mathrm{D}$ and Baxter $\mathrm{J}$ (eds.) Explaining ocean warming: causes, scale, effects and consequences, International Union for the Conservation of Nature. In press.

Hill, J., \& Wilkinson, C. L. I. V. E. (2004). Methods for ecological monitoring of coral reefs. Australian Institute of Marine Science, Townsville, 117.

Hoegh-Guldberg, O. (1999). Climate change, coral bleaching and the future of the world's coral reefs. Marine and freshwater research, 50(8), 839-866.

Hughes, T. P., Bellwood, D. R., Folke, C. S., McCook, L. J., \& Pandolfi, J. M. (2007). No-take areas, herbivory and coral reef resilience. Trends in ecology \& evolution, 22(1), 1-3.

Hupfer, P, H Grassl, J. lozán. (2001). Summary: Warning Signal from Climate. Pp.400-408 in Climate of the $21^{\text {st }}$ Century: Changes and Risk: Scientific Facts (JL Lozán, H Graßl, and $P$ Hupfer, eds.). Wissenschaftliche Auswertungen, Hamburg.

Johannes, R. E. (1975). . Pollution and Degradation of Coral Reef Communities. In Elsevier Oceanography Series (Vol. 12, pp. 1351). Elsevier.

Kartawijaya,T., I. Yulianto, Y. Herdiana, R.Prasetia, R. Anggraeni, K.M. Hasbi, H. Hazmi, H. Fain. (2012). Laporan Monitoring: Aspek sosial ekonomi dalam pengelolaan taman wisata perairan gili ayer, meno, dan trawangan 2012. Wildlife Conservation Society-Indonesia Marine Program. Bogor pp39.

Kulbicki, M., Guillemot, N., \& Amand, M. (2005). A general approach to lengthweight relationships for New Caledonian lagoon fishes. Cybium, 29(3), 235-252.

Lesser, M. P., \& Farrell, J. H. (2004). Exposure to solar radiation increases damage to both host tissues and algal symbionts of corals during thermal stress. Coral reefs, 23(3), 367-377.

Lipi. (2014). Baseline Survey Kesehatan Terumbu Karang dan Ekosistem Terkait di Taman Wisata Perairan Gili Matra. Lembaga IImu Pengetahuan Indonesia (LIPI). Jakarta. pp61.

Loya, Y., Sakai, K., Yamazato, K., Nakano, Y., Sambali, H., \& van Woesik, R. (2001). Coral bleaching: the winners and the losers. Ecology letters, 4(2), 122-131. doi: 10.1046/j.14610248.2001.00203.x 
Marnane, J.M., Ardiwijaya, R., Wibowo, J.T., Pardede, S.T., Mukminin, A., Herdiana, Y., Haryanta, S. (2004). Survei 2003-2004 di Kepulauan Karimunjawa, Jawa Tengah. Wildlife Conservation Society Asia Pacific Coral Reef Program Indonesia. Bogor. $67 p$.

Marshall, P. A., \& Schuttenberg, H. (2006). A reef manager's guide to coral bleaching.

McClanahan, T.R., N.A. Muttinge and S. Mangi. (2001). "Coral and Algal Changes after the 1998 Coral Bleaching: Interactions with Reef Management and Herbivores in Kenyan Reefs". Coral Reefs, 19, 380 391.

McClanahan, T. R., Baird, A. H., Marshall, P. A., \& Toscano, M. A. (2004). Comparing bleaching and mortality responses of hard corals between southern Kenya and the Great Barrier Reef, Australia. Marine Pollution Bulletin, 48(3-4), 327-335.

Muttaqin, E, Ardiwijaya R.L, Pardede S.T, Setiawan F, Siregar A.M, Aris M, Indra. (2011). Technical Report: Coral Bleaching Survey in Northern Aceh Seascape 2010 - 2011. Wildlife Conservation Society - Indonesia Program. Bogor.Indonesia.

Muttaqin. E, M.M Kamal, S. Haryadi, S. Pardede, S. Tarigan, S.J. Campbell. (2014). Dampak pemutihan karang terhadap ekosistem terumbu karang pada tahun 2010 di Perairan Aceh Utara. Jurnal Teknologi Perikanan dan Keluatan, 5(1), 15 - 21

NOAA. 2016. SST, Aqua MODIS, NPP, 4km, Daytime (11 microns) (Monthly Composite).

https://coastwatch.pfeg.noaa.gov/erdd ap/griddap/erdMH1sstdmday.graph

(Diakses tanggal 29 November 2016).

Odum, E.P. 1971. Fundamental of ecology. W.B. Saunders co., Philadelphia, 574 pp.

Pardede, S., S.A.R. Tarigan, Setiawan, F, Muttaqin, E., Muttaqin, A., dan Muhidin. (2016). Laporan Teknis: Monitoring Ekosistem Terumbu Karang Taman Nasional Karimunjawa 2016. Wildlife Conservation Society. Bogor. Indonesia.p 68.

Pratchett, M. S., Wilson, S. K., \& Baird, A. H. (2006). Declines in the abundance of Chaetodon butterflyfishes following extensive coral depletion. Journal of Fish Biology, 69(5), 1269-1280.
Pratchett, M. S., Munday, P., Wilson, S. K., Graham, N. A., Cinner, J. E., Bellwood, D. R., ... \& McClanahan, T. R. (2008). Effects of climate-induced coral bleaching on coral-reef fishes. Ecological and economic consequences. Oceanography and Marine Biology: An Annual Review, 46, 251-296.

Pratchett, M. S., McCowan, D., Maynard, J. A., \& Heron, S. F. (2013). Changes in bleaching susceptibility among corals subject to ocean warming and recurrent bleaching in Moorea, French Polynesia. PLoS one, 8(7), e70443. doi:10.1371/journal.pone.0070443.

Rudi, E. (2012). Pemutihan Karang di Perairan Laut Natuna Bagian Selatan tahun 2010. Biospecies, 5(1), 1-7.

Saji, N. H., Goswami, B. N., Vinayachandran, P. N., \& Yamagata, T. (1999). A dipole mode in the tropical Indian Ocean. Nature, 401(6751), 360-363.

Salim, D. (2012). Pengelolaan ekosistem terumbu karang akibat pemutihan (Bleaching) dan rusak. Jurnal Kelautan: Indonesian Journal of Marine Science and Technology, 5(2), 142-155.

Saptarini, D dan F.K. Muzaki. (2010). "Kajian Jenis dan Bentuk Pertumbuhan Karang yang Rentan Mengalami Pemutihan di Perairan Selat Madura, Jawa Timur". Prosiding Seminar JIWECC.

Schiermeier, Q. (2015). Hunting the Godzilla El Niño. Nature, 526(7574), 490-491.

Simarangkir, O. R., Yulianda, F., \& Boer, M. (2015). Pemulihan Komunitas Karang Keras Pasca Pemutihan Karang di Amed Bali. Jurnal IImu Pertanian Indonesia, 20(2), 158-163.

Smith, S. V., \& Buddemeier, R. W. (1992). Global change and coral reef ecosystems. Annual Review of Ecology and Systematics, 23(1), 89118

Tomascik, T, AJ Mah, A Nontji, and MK Moosa. (1997). The Ecology of the Indonesian Seas (Part 1 \& 2). Vol. 7. Singapore: Periplus Edition (HK) Ltd.

Walpole, E.R, Myers, R.H., Myers, R.L., Ye, K. (2012). Probability \& statistics for engineers \& scientists. Pearson education. Boston.

Westmacott, S., Teleki, K., Wells, S., \& West, J. (2000). Pengelolaan Terumbu Karang Yang Telah Memutih dan Rusak Kritis, Diterjemahkan oleh Jan Hanning Steffen IUCN, Gland, 
Switzerland and Cambridge, UK. vii + $36 \mathrm{pp}$.

Wilkinson, C.,(Ed.) (1998). Status of Coral Reefs of the World : 1998. National Library of Astralia Cataloguing-inPublication data, Townsville, Australia 184pp.

Wilkinson C.R. 2000. Status of coral reefs of the world: 2000. Global Coral Reef Monitoring Network and Australian Institute of Marine Science, Townsville, Australia 363 pp.
Wilson, J. R., Ardiwijaya, R. L., \& Prasetia, R. (2012). A study of the impact of the 2010 coral bleaching event on coral communities in Wakatobi National Park. The Nature Conservancy. 29pp.

Yulianto, I., Prasetia, R., Muttaqin, E., Kartawijaya, T., Paredede, S. T., Herdiana, Y., \& Syahrir, M. (2012). Panduan Teknis Pemantauan Ekosistem Terumbu Karang, Padang Lamun dan Mangrove. Wildlife Conservation Society. Bogor. Indonesia, 143. 